\title{
High performance of solar panel based on new cooling and cleaning technique
}

\author{
Ahmed Khudhair Abbas ${ }^{1}$, Kaleid Waleed Abid ${ }^{2}$, Osama Ibrahim Abd $^{3}$, Yousif Al Mashhadany ${ }^{4}$, \\ Abdulrahman Hammad Jasim 5 \\ ${ }^{1}$ Department of Construction and Projects, University Headquarter, University of Anbar, Ramadi, Iraq \\ ${ }^{2,3,5}$ Renewable Energy Research Center, University Headquarter, University of Anbar, Ramadi, Iraq \\ ${ }^{4}$ Department of Electrical Engineering, College of Engineering, University of Anbar, Ramadi, Iraq
}

\section{Article Info}

Article history:

Received Jun 9, 2021

Revised Sep 19, 2021

Accepted Sep 19, 2021

\section{Keywords:}

Cooling

Front water cooling

Panel efficiency

Renewable energy

Solar panel power outlet

\begin{abstract}
There is a requirement for an elective wellspring of inexhaustible and earth feasible electrical vitality because of expanded power use and an unnatural weather change issues the world over. With the accumulation of dust and the surface temperature of cells or sun-based boards increase, their productivity drops significantly. Cooling and cleaning by using water can be utilized. Proteus and MikroC software have been used to simulate the model and write the code. In this paper, is design and an experimental study shrewd customized cleaning and cooling system for photo-voltaic (PV) modules installed in Ramadi, Iraq. Which is started dependent on low essentialness coming about due to dust accumulating and high temperature conditions. This was attempted by presenting two indistinct photovoltaic modules close to one another. The fundamental unit was equipped with a model of the cleaning structure while the resulting unit was seen as standard. An upgraded cleaning and cooling methodology are gotten with the data acquiring structure. An expansion in vitality profitability of $12.4 \%$ was acquired because of lessening the operational aggravations of residue amassing and warming of the board surface. The automatic cleaning mechanism used in the system reduces human stress by washing the PV panel with low energy use.
\end{abstract}

This is an open access article under the $\underline{C C B Y-S A}$ license.

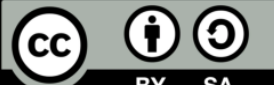

\section{Corresponding Author:}

Ahmed Khudhair Abbas

Department of Construction and Projects

University of Anbar, Ramadi, Iraq

Email: Ahmed89at@uoanbar.edu.iq, kaleid.waleed@uoanbar.edu.iq

\section{INTRODUCTION}

The increasing demand for renewable energies sources, particularly solar energy to preserve the environment and cleanliness and lack of maintenance compared to traditional sources of energy, although the initial cost of these projects, that made international establishments compete to reduce the prices of the fitting of these solar systems to win bids large projects for the construction of solar plants despite the widespread and necessary to face several problems [1], [2]. Renewable energy plants and systems, especially solar energy. Abundant year-round solar brightness in several nations, including the Middle East, North Africa and technological development, solar energy has emerged as a cheap, efficient and environmentally friendly solution [3], [4].

The most important problems, such as volatile cement particles in the air construction, polluted air inside big cities and dust storms, especially in areas with a desert climate, which causes the accumulation of layers that completely prevent the trace from solar radiations [5], [6]. furthermore, the heterogeneity of these layers creates heterogeneous shades as well, which negatively influence the efficiency and functioning of a virtual solar panel according to the hotspots appearing, it produces electrical currents eddy between solar 
panels due to asymmetry of internal resistance of solar panels. In turn, will form with other weather factors a layer which avoids the track of solar radiation to the panels well and thus reduce the overall yield of solar systems in addition to lifetime, these ranges from $20 \%$ to $5 \%$ of the total system output [7].

Such drop, which is frequently measured by the soiling frequency, is strongly influenced by four problems; 1) the weather conditions, 2) physical characteristics, like the size of dust particulates. 3) Roughness of photovoltaic panel surfaces and 4) the environmental site [8]. To protect the environment from pollution, the cleanest and perhaps most available energy sources are solar energy. Governments are endeavouring to enact laws and regulations to regulate work and make the most of the outputs of these energies [9]. The angle of the solar cell, the Location is important where the more horizontal the solar panel the more dust accumulates consequently, the arrival of solar radiation is reduced, resulting in the less overall production of the solar system [10], [11].

In hot climates such as the Arabian Peninsula and Iraq, where solar cells are sensitive to heat, many researchers have been interested in and published several kinds of research on cleaning and cooling because of its obvious importance in the overall return of the solar system, there are several types of research at present and short for time and effort working in both numerical and experimental ways to obtain optimization techniques [12]. Furthermore, it was detected which When there is a dust-storm and a rain-fall at once, Therefore the soiling level is increasing when the sands are gathered Which will make cleaning more difficult later [13]. Outcomes of observing the physical appearance of sands in Saudi-Arabia disclosed that installation of dust different considerably respects with climate. Composition of crustal elements such as ( $\mathrm{Si}, \mathrm{Ca}, \mathrm{Na}, \mathrm{Al}$, $\mathrm{Fe}, \mathrm{K}$, and $\mathrm{Mg}$ ) showed that enlarged from (45-68\%) Following storm of sand, specifying that starting point of the storm-set dust is primarily due to non-anthropogenic causes; but the opposite are proper in standard or normal environments [14].

As the temperature of the solar panel increases its open-circuit voltage so the conversion efficiency is decreases. By comparison, a change in short circuit seems to be low because of the temperature is increased. Thus, the performance of the system panel reduces because its surface temperature is increased [15], [16]. This study matters at consuming the front cooling and cleaning technique to decrease the temperature of solar panels. This is to improve the solar panel modules power output and efficiency using cleaning and cooling the module front surface for Heat dissipation with water. Solar panel modules efficiency and Power outlet lessens when the surface temperature of the solar panel modules rises due to hotness and partial shading caused by the soiling rate [17]. The change in the magnitude and time of the spray water does have a clear impact on the improvement of solar panel efficiency. Therefore, the process in general is among the most significant parts in improving system performances [7]. How can the solar panel modules produce maximum power continuously from the sunlight peaks. For earlier studies, the above-cited calls for attention to limit the influence of heat, partial dust and shade on outcome and performance of photo-voltaic (PV) panels in a sunny country as Iraq (Middle Eastern country) where this job was applied in practice.

There is a lot of other research is underway on solutions to approach overheating problem. Heat energy from the solar panel can be lost through convection, radiation, and conduction, and two main cooling manners could be acknowledged, which include passive cooling, that involves normal methods to remove heat without power consumption as well as active cooling, as there is a need to consume energy to remove heat [18], [19]. For energy efficiency reasons idea of active cooling and cleaning is included in this research study. The cooling system process consists of sprinkling water on the panel surface whereas the brush is on for cleaning made of Rubber is joined with spraying system to the front of the panel.

\section{MATHEMATICAL MODEL FOR PERFORMANCE OF SOLAR PANEL}

\subsection{Efficiency of solar panel}

Ambient temperature or external temperature plus the temperature of solar panel, this affects the performance of the solar panel, since the voltage of a solar panel as well as the current depending also on temperature. Solar panel system maximum power point (MPP) as explained here in [20] is,

$$
P_{m p}=V_{m p} \times I_{m p}=V_{o c} \times I_{s c} \times F F
$$

where:

$P_{m p} \quad$ : Denotes for the solar panel module maximum power point at load.

Vmp : Denotes for the maximum voltage at load.

Imp : Denotes into maximum current at load.

FF : Denotes to fill factor (FF),

Voc : Indicate open circuit voltage

Isc : Denotes short current circuits 
The solar cell efficiency as in [21] that's the ratio of solar panel energy production divided first by sun's power supply, as represented in (2).

$$
\eta=E_{\text {out }} / E_{\text {in }}
$$

Performance in solar cells may also come in the form of (3),

$$
\eta=P_{\max } /(E \times A)
$$

wherever $A$ the surface area of the solar panel in $\mathrm{m} 2$, (E) is a solar radiation with standard test condition (STC) $(\mathrm{W} / \mathrm{m} 2)$ as well as $P_{\max }$ is the Maximum PowerPoint. The solar cell system performance could also be described utilize the correlation in [22]as,

$$
\eta_{\mathrm{pv}}=\eta_{\mathrm{rT}}\left[1-\beta\left(T_{\mathrm{pv}}-\mathrm{T}_{\mathrm{rT}}\right)\right]
$$

where $\left(\eta_{\mathrm{pv}} \mathrm{s}\right)$ symbolizes the Solar cell performance, $\left(\eta_{\mathrm{rT}}\right)$ is an effectiveness of solar cells only at reference temperature, that is ordinarily at $25^{\circ} \mathrm{C},\left(T_{\mathrm{pv}}\right)$ is the solar panel cell's temperature, $(\beta)$ symbolizes temperature. Outlet factor as well as (TrT) is the Photovoltaic or cell reference temperature.

\subsection{Effect temperature of solar panel}

Impact of the temperature on the solar panel could be explained by means of a calculation for solar array outlet power as in [17] as,

$$
\mathrm{P}_{\mathrm{pv}}=\mathrm{Y}_{\mathrm{pv}} \times \mathrm{f}_{\mathrm{pv}}\left(\mathrm{G}_{\mathrm{T}} / \mathrm{G}_{\mathrm{T}, \mathrm{STC}}\right)\left[1+\alpha_{\mathrm{p}}\left(\mathrm{T}_{\mathrm{c}}-\mathrm{T}_{\mathrm{C}, \mathrm{STC}}\right)\right]
$$

where,

$\left(\mathrm{Y}_{\mathrm{pv}}\right) \quad$ : Rated of the capacity of the solar array, that involves which its outlet of power under standard test condition (STC) measured (KW)

$\left(\mathrm{f}_{\mathrm{pv}}\right) \quad$ : Solar panel derating factors $(\%)$

$\left(\mathrm{G}_{\mathrm{T}}\right) \quad$ : Solar irradiance Denotes on the Photovoltaic module in the present time step $\left(\mathrm{KW} / \mathrm{m}^{2}\right)$

$\left(\mathrm{G}_{\mathrm{T}, \mathrm{STC}}\right)$ : Incident Irradiance at (STC) $(1 \mathrm{Km} / \mathrm{m} 2)$

$\left(\alpha_{\mathrm{p}}\right) \quad$ : Temp coefficients of outlet energy $\left(\% /{ }^{\circ} \mathrm{C}\right)$

$\left(\mathrm{T}_{\mathrm{c}}\right) \quad$ : Solar temp in the present time step $\left({ }^{\circ} \mathrm{C}\right)$

$\left(\mathrm{T}_{\mathrm{C}, \mathrm{STC}}\right)$ : The solar cell temp beneath $(\mathrm{STC}),\left(25^{\circ} \mathrm{C}\right)$

The solar panel temp, the outlet conversion efficiency is basically supported throughout the calculation of an outlet energy variance created from its (STC) panel from measured results [23], Temp, The outlet power coefficient for such a solar cell was -0.44 percent/C. In addition, test measured solar panel derivation function. For the reason that, solar panels Instant calculations throughout the arena will demonstrate that perhaps the energy of the solar panel is various from those of the nameplate reading. Other environmental influences like cloud, heavy dust and shadow. may minimize the photovoltaic module's performance. Experimenting with the PV unit using a characteristic impedance factors around 0.95 indicates the test delivered energy reading in the STC that was 5 percent less then nameplate classification of a photovoltaic producer. Equation of power out-put of the photovoltaic array the whole element is used for calculate factors such as wire loss and shading. This work utilized a characteristic derating factor for 0.75 to show cause of total losses as well as a characteristic derating factor with 1.0 for just an ideal condition of fixing. The solar panel performance could be detail like in equation.

$$
\eta_{\mathrm{mp}, \mathrm{STC}}=\mathrm{Y}_{\mathrm{pv}} /\left(\mathrm{A}_{\mathrm{pv}} \times \mathrm{G}_{\mathrm{T}, \mathrm{STC}}\right)
$$

Where

$\left(\eta_{\text {mp,STC }}\right)$ is the efficiencies of the solar panels under standard test condition (\%)

$\left(\mathrm{Y}_{\mathrm{pv}}\right)$ Denotes the solar panels rated outlet power at STC $(\mathrm{KW})$

$\left(A_{p v}\right)$ Surface area of the PV-module $(\mathrm{m} 2)$

$\left(\mathrm{G}_{\mathrm{T}, \mathrm{STC}}\right)$ Represent the irradiation at $\mathrm{STC}(1 \mathrm{KW} / \mathrm{m} 2)$

By substituting, in (5),

The solar panel efficiency rearrangements to, 


$$
\eta_{\mathrm{mp}}=\mathrm{P}_{\mathrm{pv}} /\left(\left(\mathrm{A}_{\mathrm{pv}} \times \mathrm{f}_{\mathrm{pv}} \times \mathrm{G}_{\mathrm{T}}\right)\left[1+\alpha_{\mathrm{p}}\left(\mathrm{T}_{\mathrm{c}}-\mathrm{T}_{\mathrm{C}, \mathrm{STC}}\right)\right]\right)
$$

\subsection{The solar panel temperature coefficient of power}

For the solar panel, this coefficient or parameter specifies the extent to that the solar cell temperature affects the energy produced by the solar panel. The temperature coefficient is set to the minus amount which is because as the solar cell temperature Increases, energy outlet decreases. The temperature coefficient of the 250-watt solar panel used in this experiment is $-0.44 \% / \%$ that means that the maximum power unit experience has been reduced for each temperature degree above $\left(25^{\circ} \mathrm{C}\right) .(-0.44 \%)$ The outlet power decreases and the unit surface temperature decreases $25^{\circ} \mathrm{C}$ when temperature is above $25^{\circ} \mathrm{C}$, the power output is estimated to rise above the estimated value of the solar panel [24].

\subsection{Effects of heat on photovoltaic module}

The temperature of solar panel are rises due to sun exposure, heat generation activates in this manner. When it influences a point where the outlet of the solar panel drops, the increasing of temperature is evident over time. This overheating is one of the main challenges facing the smooth operation of the solar panel due to over exposure to the solar irradiance needed as well as rise outdoors temperatures. Overheating decreases performance and also the panel outlet energy. Efficiency, in addition to outlet power, greatly reduces. When temperatures rise, the extent of the moderation is a function of the materials used in the manufacture of PV cells [25]. In order to solve the challenge of high temperature as well as losing of valuable power so the cooling system for photovoltaic cell is essential.

\section{GENERAL DESCRIPTION}

The cooling and cleaning project have been achievement. An observational setup was established to analyse the effect of the cooling and cleaning system on photovoltaic (PV) panel efficiency. The cooling system have been used water, Water is sprinkler on its front photovoltaic through sprayed systems. Furthermore, rubber brush has been used for removing dirt on the design. Figure 1 shown the flowchart of proposal design.

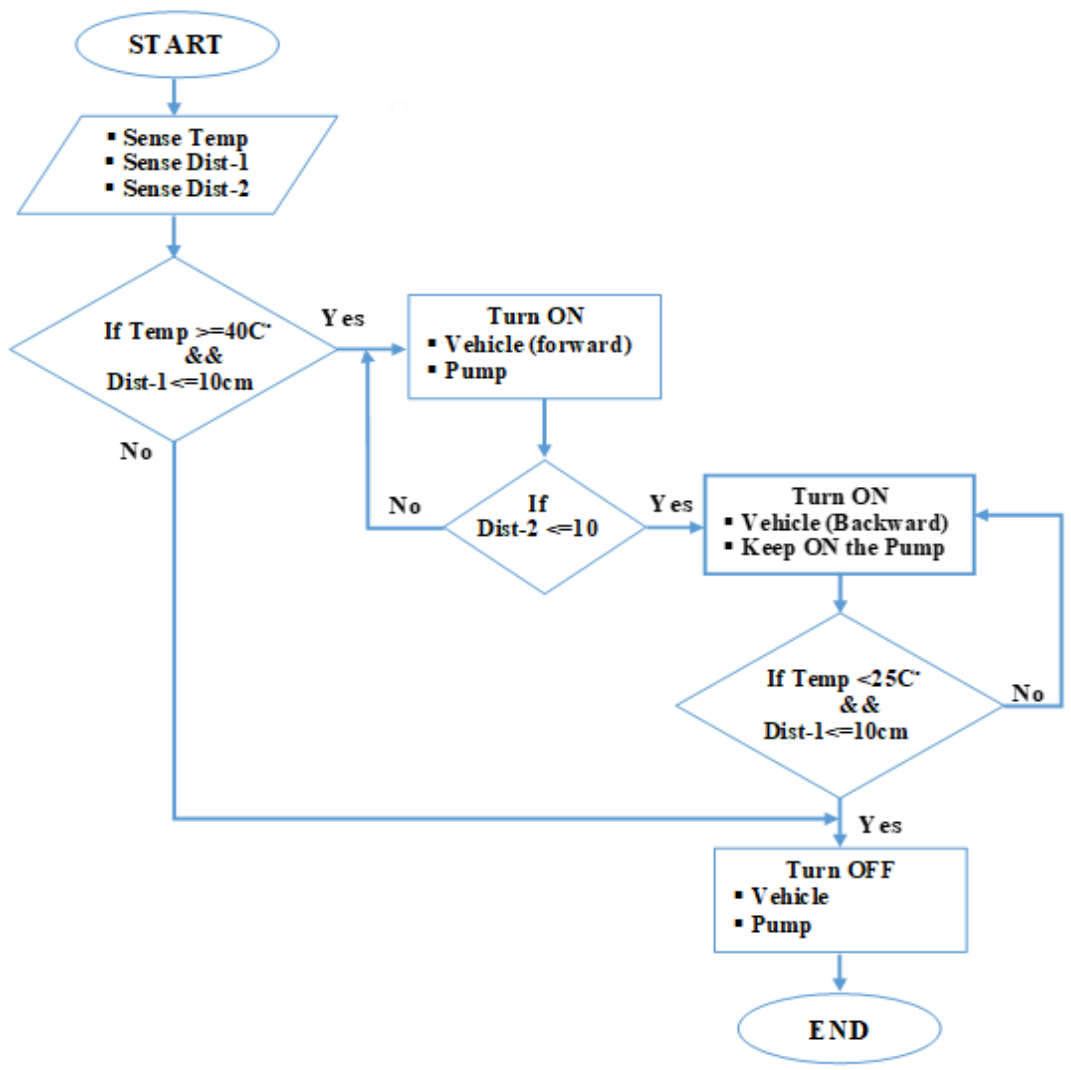

Figure 1. Flowchart of proposal design 


\section{SIMULATION DESIGN}

At first, the design of the project has been done on simulation by using Proteus software and generated the code by using Arduino Software. This design using the Arduino-Uno board as the control system that originally stood out due to its robustness, cost as well as developer community in comparative analysis with some other open-source platforms. The monitoring system implemented are focused on Arduino application, which is records that data from the sensors. The project have been set the reading a temperature sensor each 15 minutes. Figure 2(a) describes the simulation diagram based on Proteus software and view of water spraying technique. Figure 2(b) shows a detailed design schematic of the experimental setup for the cooling and cleaning system.

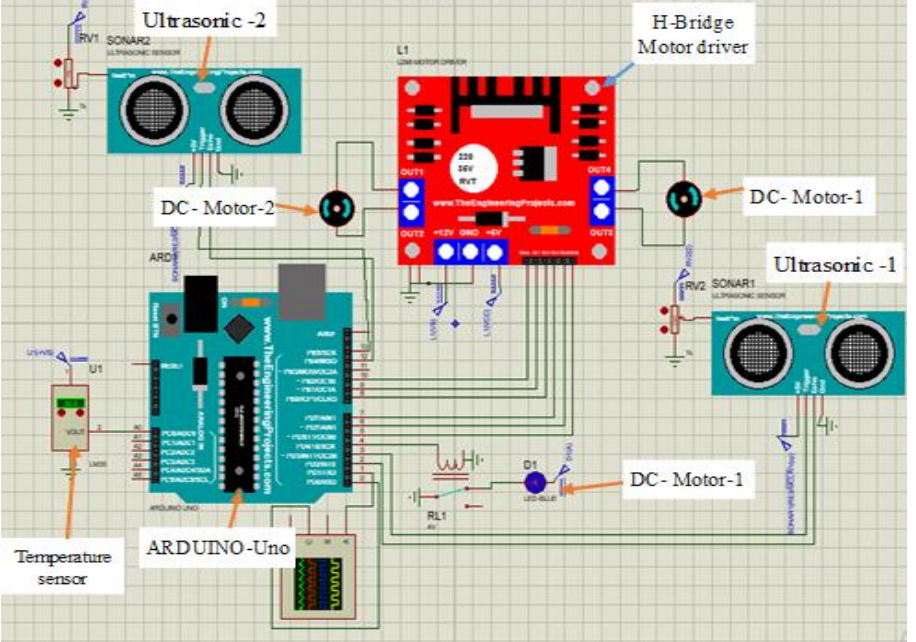

(a)

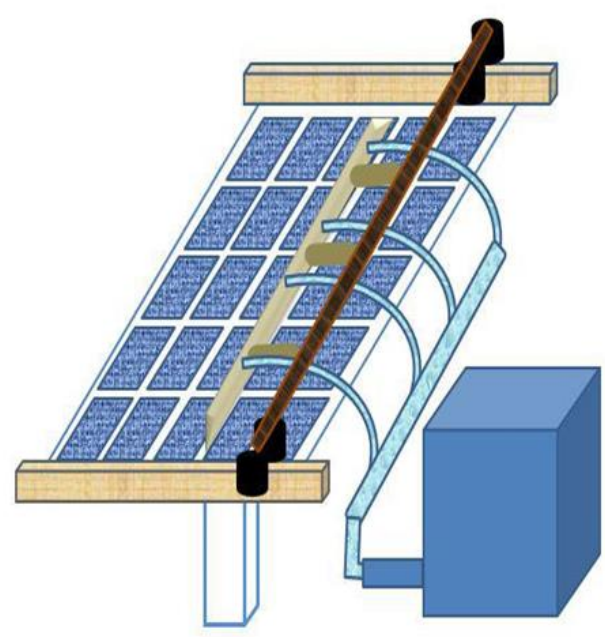

(b)

Figure 2. Design of; (a) simulation of proposal system and (b) schematic of cooling and cleaning system

\section{PRACTICAL RESULTS}

An experiential system was established to analyse the impact of a cleaning and cooling system utilizing water for performance of solar panel energy. The solar energy system is built at the University of Anbar in renewable energy research center (RERC) in Iraq. The experimental setup consists of single panel of solar panel. Table 1, shows the numerical values of electrical and mechanical parameters of solar panel.

Table 1. Characteristics of solar panel [26]

\begin{tabular}{lc}
\hline \multicolumn{1}{c}{ Characteristics } & Values \\
\hline Power rating Pmp & $(250) \mathrm{W}$ \\
Optimum-operating-voltage (Vmp) & $(30.7) \mathrm{V}$ \\
Optimum-operating-current (Imp) & $(8.15) \mathrm{A}$ \\
Operating-circuit-voltage (Voc) 37.4 & $(37.4) \mathrm{V}$ \\
Short-circuit-current (Isc) & $(8.63) \mathrm{A}$ \\
Operating-module-temperature & $(-40-85)^{\circ} \mathrm{C}$ \\
Temperatures coefficient of Pmax & $(-0.44 \%)^{\circ} \mathrm{C}$ \\
Temperatures coefficient of Voc & $(-0.34 \%)^{\circ} \mathrm{C}$ \\
Temperatures coefficient of Isc & $(-0.060 \%)^{\circ} \mathrm{C}$ \\
\hline
\end{tabular}

The solar panel cooling and cleaning device consists which includes a pole (the length of the pole are possible to change) on which the ends of it are installed by two small vehicles and four sprays water to sprays water distributed regularly on solar panel and rubber brush for removing dirt and mud strongly cleaning. Furthermore, the connected pipes and recycling water system. The cooling and cleaning mechanism is controlled by smart controllers and sensors of temperature and sensor of distances and other components. The involved cooling and cleaning system served as a photoelectric efficiency test. Moreover, the details specification of the parameters of system design.

ISO 9060 Pyranometer/First class/RS-485/Analog

SMP6 (Specifications)

Spectral range (20\% point) 280 to $3000 \mathrm{~nm}$ 
Spectral range (50\% points) 285 to $2800 \mathrm{~nm}$

Response time $(63 \%)<1.5 \mathrm{~s}$

Response time $(95 \%)<12 \mathrm{~s}$

Zero offset $\mathrm{A}<10 \mathrm{~W} / \mathrm{m}^{2}$

Zero offset $B<4 \mathrm{~W} / \mathrm{m}^{2}$

Directional response (up to $80^{\circ}$ with $1000 \mathrm{~W} / \mathrm{m}^{2}$ beam) $<15 \mathrm{~W} / \mathrm{m}^{2}$

Temperature dependence of sensitivity $\left(-40^{\circ} \mathrm{C}\right.$ to $\left.+70^{\circ} \mathrm{C}\right)<3 \%$

Analogue output (-A / -V version) 4 to $20 \mathrm{~mA} / 0$ to $1 \mathrm{~V}$

- $\quad$ Some additional components with were used to cool and clean the photovoltaic panels project and it be shown in Table 2 with the details as (temperature data logger, solar panel of peak-output and centrifugal pump of power.

Table 2. Shows the characteristics, and values for equipment's that have been used in this project

\begin{tabular}{lc}
\multicolumn{1}{c}{ Characteristics } & Values \\
\hline Solar panel of peak-output & $250 \mathrm{~W}$ \\
Temperature data logger & $-100^{\circ} \mathrm{C}-300^{\circ} \mathrm{C}$ \\
Arduino-Uno. - Six PWM Channels & $5 \mathrm{VDC}$ \\
Nozzles spray gardening water cooling brass sprinkler & 4 \\
DC-Motors & $5 \mathrm{VDC} / 4$ \\
Temp. Sensor & 1 \\
Ultrasonic Sensor HC-SR04 Distance & $2 \mathrm{~cm}$ to $450 \mathrm{~cm} / 2$ \\
H- Bridge Motor Drive & $\mathrm{L} 298 \mathrm{~N}$ \\
Centrifugal pump of power & $12 \mathrm{VDC} 30 \mathrm{~W}$ input \\
\hline
\end{tabular}

Moreover equipment's

- $\quad$ Storage water tank with a continuous water supply.

- $\quad$ Drain tube for to pick up the water to return-back it to the reservoir

- $\quad$ Thermography camera (Flir Company) to check the cooling uniform or not.

- $\quad$ Infrared thermometers.

- $\quad$ Digital output 2-wire RS-485

In addition, other equipment used includes: set of screwdrivers, watering can, Pyranometers, Solar panel holder, and flexible cable. Figure 3 shows the practical of cooling and cleaning of photovoltaic solar system. The solar panel was cooled so as to evaluate the cooling and overheating effect of solar cell efficiency. Solar panel was cooled for first day in August 2020 as well as the cooling experiment started from 8:00 A.M. till 6:00 P.M. Using controlled. The practical testing's are done in August because that is the hot duration, so achieving success in cooling a photovoltaic power throughout this period means that the panels could be cooled by using this suggested cooling method till the rest of year.
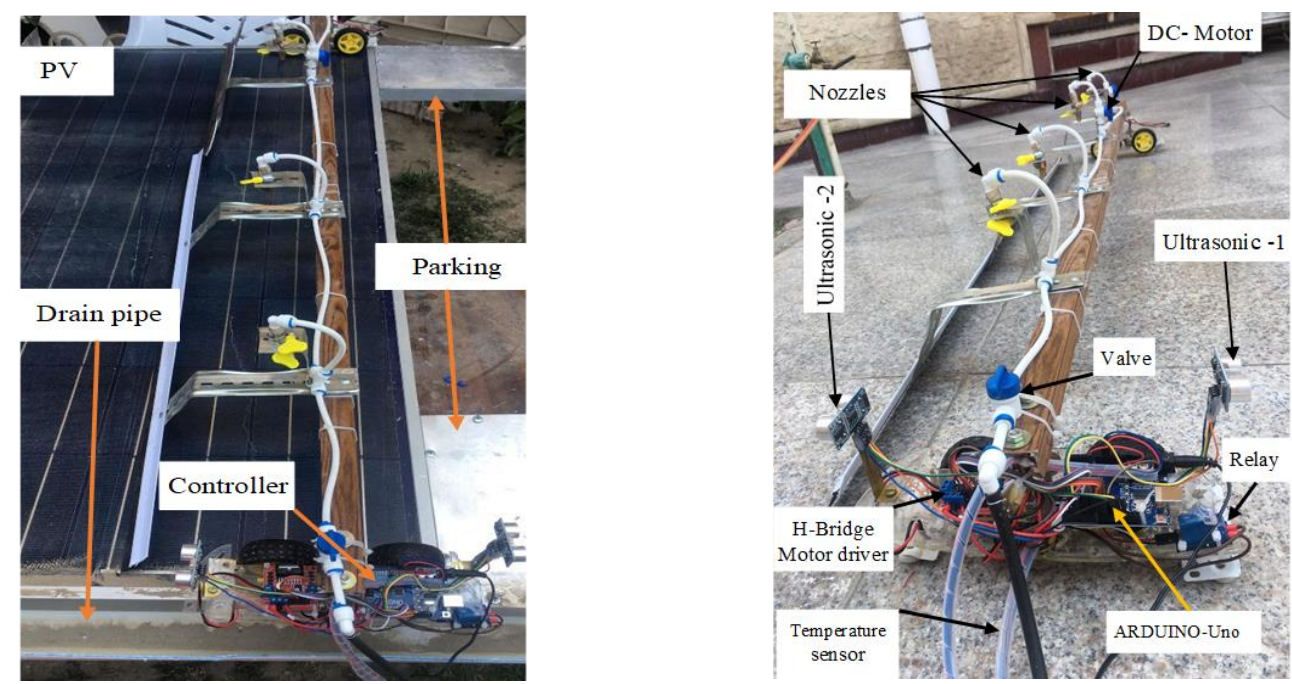

Figure 3. Shows the practical of cooling and cleaning of photovoltaic solar system 
The cooling and cleaning system will work automatically. The controller always sense the temperature by using thermocouple (K-Type) and sense the distance by suing Ultrasonic then send the data to Arduino to process it. the cooling system turned off when the temperature less than $25^{\circ} \mathrm{C}$ and the distance of Ultrasonic-1 less than $10 \mathrm{~cm}$. the cooling system have two conditions to turn on, the first condition, at the temperature equal or more than $40^{\circ} \mathrm{C}$ (possible to change the temperature) furthermore. The second condition is the distance of Ultrasonic-1 when it equal or less than $10 \mathrm{~cm}$, the DC-motors will be move on (Forward direction) To the end of the solar panel as well as the water pump, the water is pumped on PV panel for cooling the system.

When the Ultrasonic-2 reach the end of solar system (equal $10 \mathrm{~cm}$ or less) the controller will give the order to change the polarity for DC-Motors so will be return back, cooling system may move more than one time. The cooling system will be off with two conditions will be happened, the first condition with the temperature of solar panel be less than $25^{\circ} \mathrm{C}$ and also when the Ultrasonic-1 reach to (distance $10 \mathrm{~cm}$ or less) then will be off. The system could be on parking area to avoid effect of shade on solar system to get the highest efficiency.

To prevent sucking dust, the pump pulls the water into a suction tube from the center of the tank. The suction tube is made up of a check valve as well as a colander for prevents a big particle from through to which could harm the pump. Water sucked flows into the water filter, and afterwards the solar panels are sprayed by water for cooling the system. Water are sprinkled by utilize nozzles, positioned on the top of system, as shown in the Figure 3. Afterwards, water utilized for cooling systems is gathered at the bottom of the solar panels by drain pipe thereafter, returned it back to the storage tank. This concept has been used to reduce water consumption which is important in desert regions. That water tank can be buried underground to keep irradiation from the sun from warming up as well as to cool the water in the tank through surrounding soil. The warm water arriving from the solar panel will be cooled by combining inside the tank with a significant volume of cold water.

The panel surface temperature is calculated by means of temperature sensors (thermocouple placed at back-surface) of solar panel. The outcome energy, solar radiation as well as temperature have whole been tracked and utilize information an acquisition systems. For additional calculation and analysis, all measurements are saved. It has been found the loss of water by month due to evaporation to be approximately $4.7 \%$ of the original total volume of water tank. Thus this system could be assumed to be sufficient for photovoltaic station built in the desert.

\subsection{Measurement of solar panel temperature}

In this research, several temperature measuring of temperature were booked, temperatures at the back of the two solar panels was booked using the thermography camera to help us how to distribute the best places of nozzles. Measuring the temperature by probe at points at the buck solar panel surface, from order not to lead to energy loss by placing on the front of the board due to the partial shade a further step taken has been the sprinkle of water on the solar panel accomplished at depend on temperature sensor, to help moderate the temperature. Temperature measuring through the test were done every 15 minutes, this were detected after spray the panel, because of rising ambient temperature in the site, temperature of panel increases almost immediately so the system will run automatically. As for the water used to cool the panel, it is at the same room temperature and we did not use cool water to preserve the physical properties of the solar panel.

\subsection{Measurement of electric power for solar}

Panel voltage and current were obtained for the solar panel with the help of a multi-meter that were used ammeters and voltmeter, respectively, had battery Used in this experiment. With the production station of the solar panel short circuit with wires. The output voltage of the unit is easily measured. On the contrary, we had the resistor $10 \Omega$ is coupled to the solar panel. Current and voltage measuring are used from of the minimum resistance to the maximum. Another measurement used are including current and voltage as panel is from an open circuit, as well as voltage, current for the next resistance values is $1.5 \Omega, 3,5,6,7,8,9,10$. The setup achieved electricity production by capacity Solar panel for generating current through the load and the voltage during the same variables resistor simultaneously in continuous radiation. Express the power outlet panel is as given in (1).

\subsection{Site selection and tilting}

This test took place in university of al Anbar, Iraq sited within $33^{\circ}{ }^{\circ} 5^{\prime} 14.02 " \mathrm{~N}$ Latitude and 43 ${ }^{\circ} 18$ '28.01"E longitude with the solar panel Tilted accurately to ensure maximum reception of radiation from the sunlight. After several attempts to determining an optimal angle of inclination at the building roof for our centre and its affinity 33 degrees by measuring the electrical power coming out of the solar panel during close periods of the day. Pyrometer readings were recorded between 8 morning till 6 evening on a daily basis 
in a 30 minutes break as described in Figure 4(a). The radiation is low off the sun during the sunrise in the morning and raises the intensity of the sunlight, but with small decreases before 13:30 as the solar radiance reaches its limit, and then there are some rise and fall in radiation, but as the sun sets, radiation gradually reduces. The ambient temperature readings, and the temperature in different sections of the solar panel combined with solar radiation booked at breaks of 30 minutes as have seen in Figure 4(b). All the readings of ambient temperature rises with a rise in Sunlight duration, there is a rise in both front Surface and back surface temperature of solar panels.

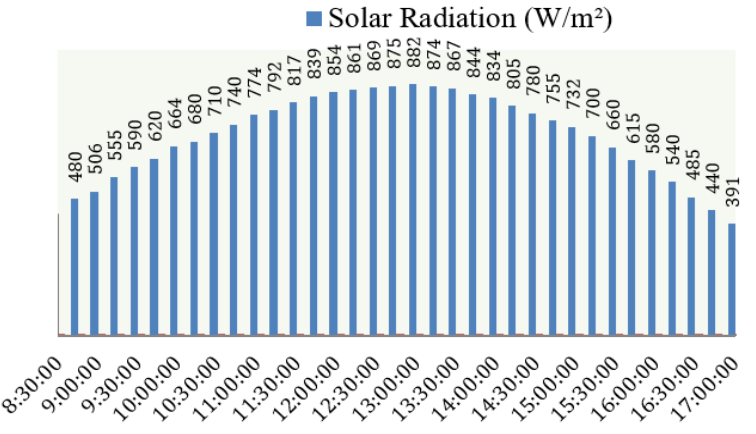

(a)

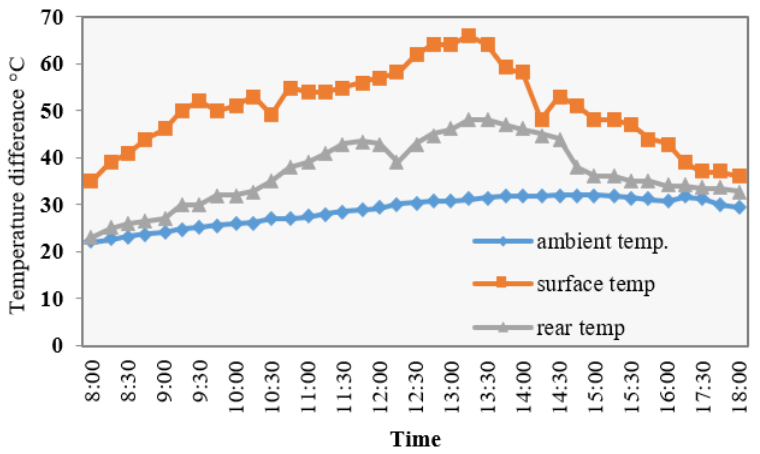

(b)

Figure (4). A graph of; (a) solar radiation vs. time, (b) Ambient temperature, surface and back surface temperature $\left({ }^{\circ} \mathrm{c}\right)$ vs. time

\section{ANALYSIS OF MAXIMUM POWER POINT BASED ON OPTIMAL LOAD}

This analysis for maximum power point for proposal design was apply with practical results, which are collect from many practical tests. In Figure 5(a) the increasing of maximum voltage (Vm) gradually when the load bank rises, in either of the three instances, it could be seen which the maximum Vm rises achieved with such a load bank increasing trend. On the other hand. The maximum voltage reached when the panel is cooled with water to room temperature is greater, as well as which achieved from panel water cooling is more than which achieved from panel with-out using the proposed system. In each case, the magnitude current flow obtained in Figure 5(b) decreases as load rises, however with the maximum current amount achieved with water at room temperature, magnitude values of the current flow obtained from water cooling are observed. From Figure 5(c) The maximum of power wrote down obtained, growths with the peak power gained at a load bank of $5 \Omega$, the power outlet shows which the outcome acquired with the solar panel, watercooling and cleaning systems is additional than the power outcome done with solar panel without proposed system and also. The peak power outcome was realized with water-cooling and cleaning systems of solar panel front surface with water at room temperature.

To deal with the temperature power factor, derivative factor estimate of a deliberate power outlet of 0.75 and 1 using (5), the findings are as shown in Figure 6(a), when the solar radiation increases, the temperature of panel rises, but with a decrease at 13:30PM, 14:30PM and 15:30PM during which the panel was cooled with water. The experiment reported a significant rise in output power at every cooling point except at 13:30PM where even with water-cooling it reported a decrease in power output and it was attributed to a decrease in the solar irradiation encountered at the time. The derating factor (d.f.) of 0.75 and 1 as shown in Figure 6(b) for power outlet show that the test considers setup losses at a 0.75 derating factor (d.f.) and no losses at a 1 . The graphs display power outlet changes every time, along with variations in the strength of the sun or air temperature due to ups and downs. At 13:15 noon, the system reached peak-power together at a derating factor (d.f.) of 0.75 and 1 because at the time and at the temperature the solar irradiation was high. The solar panel consisted of $45^{\circ} \mathrm{C}$. This test considers the power outlet values that were found with a 0.75 derating factor (d.f.) to excuse losses.

The cleaning and cooling water from the solar panel and the solar panel cooling Surface unit to $15^{\circ} \mathrm{C}$ at 12:30 pm, 13:30 pm Afternoon The result shown in Table 3 is generated. Photovoltaic power unit 250 watts is an $75 \%$ melting factor means that the expected power outlet from the unit is in The ideal mode is 187 It was done watts because the maximum power predicted from of the photovoltaic unit was 187 watts, the outcome power exceeds 187 watts addition. In Table 3 the highest power outlet is achieved from the solar panel with water cooled from the unit surface To 15 degrees Celsius at 12:30 PM, 13:30 PM. 


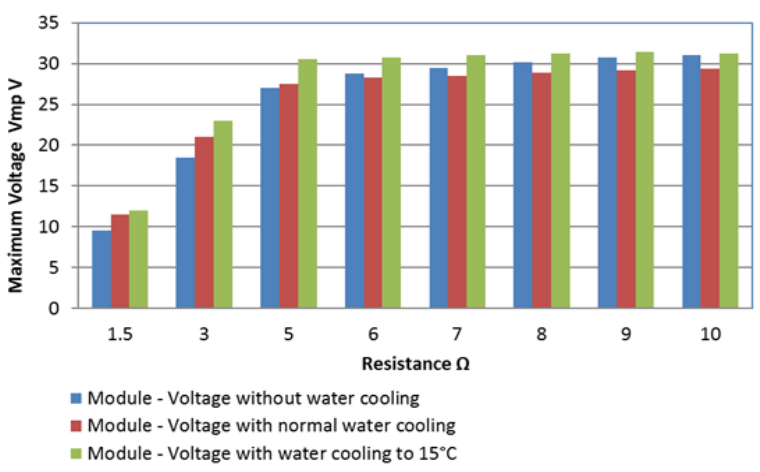

(a)

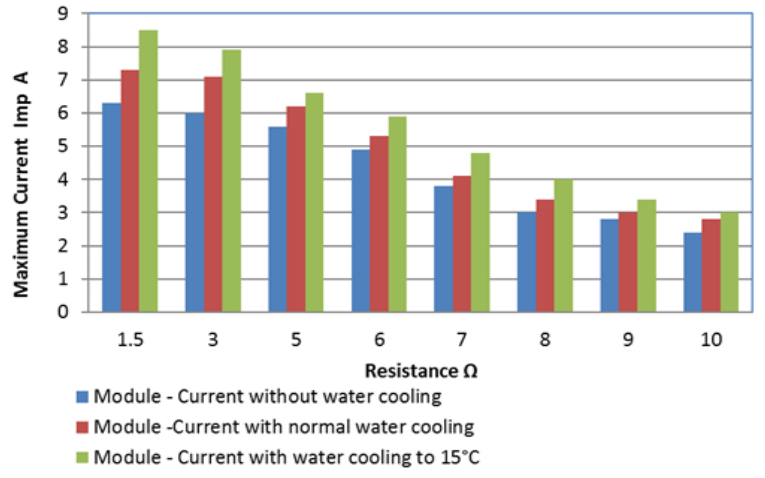

(b)

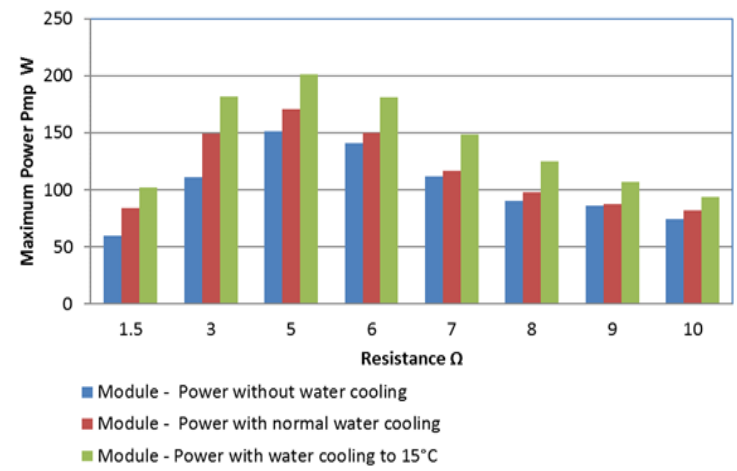

(c)

Figure 5. Maximum of; (a) voltage measured versus resistance, (b) current measured versus resistance, (c) power measured versus resistance

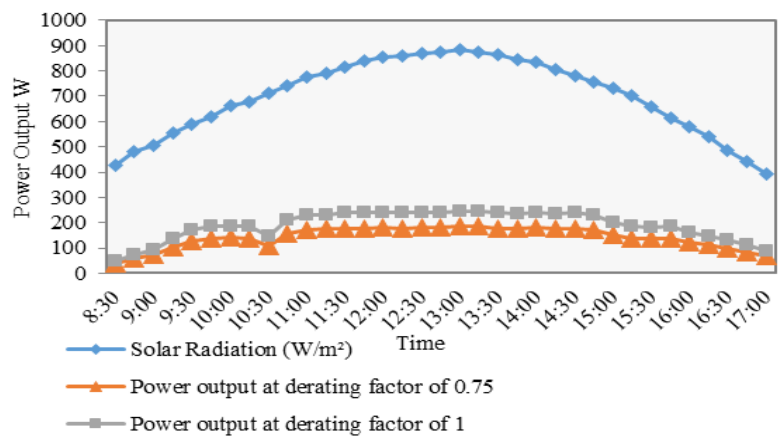

(a)

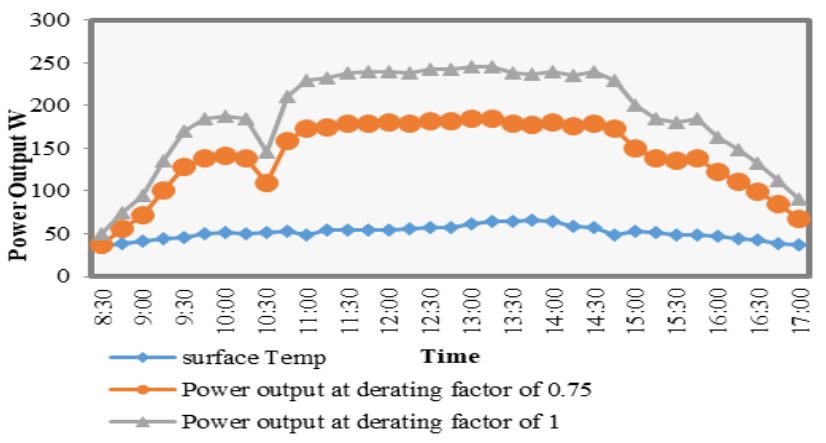

(b)

Figure 6. Power output of; (a) solar radiation vs time at derating factor of 0.75 , (b) surface temperature vs. time at derating factor of 0.75 and 1 
Table 3. Outlet power of solar panel, $\mathrm{f}_{\mathrm{pv}}=75 \%$

\begin{tabular}{|c|c|c|c|}
\hline Time & $\begin{array}{c}\text { Solar panel without cleaning and } \\
\text { cooling power outlet (w) @ a fpv = } \\
75 \%\end{array}$ & $\begin{array}{c}\text { Solar panel without cleaning and } \\
\text { cooling power outlet (w) @ a fpv = } \\
75 \%\end{array}$ & $\begin{array}{l}\text { Solar panel cleaning and cooling of surface of } \\
\text { module to } 15^{\circ} \mathrm{C} \text {, outlet power (w) @ a fpv = } \\
75 \%\end{array}$ \\
\hline $12: 30$ & 185 & 195 & 205 \\
\hline $13: 30$ & 188 & 197 & 208 \\
\hline
\end{tabular}

The first attempt that cooling the system by water actually occurred at approximately 12:30 P.M.; but before, the outlet power was obtained from panel cooling and cleaning system gradually rises above that of the panel without a cooling and cleaning system. That implies a slim increase in solar panel production. The water flow on the front surface of the solar panel may act like a mirror it reflects solar irradiance from of the solar panel through the water Spray on front panel surface, with a view to minimizing this, the water was not sprayed onto the surface of the solar panel always, in its place, it has been completed irregularly. Additionally, because of increase the effectiveness of the solar panel while water is flowing on Surface of module, semi-transparent PV unit was used for experiment. The solar panels carry a risk experiencing an increased leakage current that will lead to a possibility caused by the degradation of the solar panels.

The results show the cooling on the front side produces better outcomes over back side cooling. The energy of electric outlets obtained from cooling system of solar panels in extreme weather environments and it showed the electrical efficiency increased. The solar panel's temperature is lowered by utilize of water spray.

\section{CONCLUSION}

This study presented the influence of photovoltaic panel temperature as well as dust. When the cell temperature increments and prompts a reduction in the electrical productivity of the cell. An improved cleaning and cooling methode has been executed to address the essentialness drop achieved by dust and high temperature conditions. Utilizing a water-spray and cleaning device which is working automated. The findings indicate that the technology improves the total electrical efficiency considerably of $12.4 \%$. Morever, the surface temperature of the PV board was held under $30^{\circ} \mathrm{C}$ in summer in Iraq. The voltage and power was expanded by cooling and cleaning the PV board, a greatest increment in the electrical effectiveness of the board, which plainly portrays the improvement in board execution and supports the utilization of water-cooling innovation in concentrated photovoltaic (CPV) frameworks with water utilization sensible. So we can say that the proposition configuration can be considered as a reasonable and solid model of refrigeration framework for sun oriented board system.

\section{REFERENCES}

[1] N. K. Memon, "Autonomous vehicles for cleaning solar panels", Proc. 2016 Int. Renew. Sustain. Energy Conf. IRSEC 2016, pp. 633-637, 2017, doi: 10.1109/IRSEC.2016.7983975.

[2] Y. Mahmoud, W. Xiao, and H. H. Zeineldin, "A Simple Approach to Modeling and Simulation of Photovoltaic Modules," A Simple Approach to Modeling and Simulation of Photovoltaic Modules, vol. 3, no. 1, pp. 2011-2012, 2012, doi: 10.1109/TSTE.2011.2170776.

[3] D. Deb and N. L. Brahmbhatt, "Review of yield increase of solar panels through soiling prevention, and a proposed water-free automated cleaning solution," Renew. Sustain. Energy Rev., vol. 82, no. April, pp. 3306-3313, 2018, doi: 10.1016/j.rser.2017.10.014.

[4] K. N. D. Malamaki and C. S. Demoulias, "Analytical calculation of the electrical energy losses on fixed-mounted PV plants," IEEE Trans. Sustain. Energy, vol. 5, no. 4, pp. 1080-1089, 2014, doi: 10.1109/TSTE.2014.2323694.

[5] N. K. Kasim, N. M. Obaid, H. G. Abood, R. A. Mahdi, and A. M. Humada, "Experimental study for the effect of dust cleaning on the performance of grid-tied photovoltaic solar systems," Int. J. Electr. Comput. Eng., vol. 11, no. 1, pp. 74-83, 2021, doi: 10.11591/ijece.v11i1.pp74-83.

[6] M. A. M. Abdelsalam et al., "Experimental study of the impact of dust on azimuth tracking solar PV in Sharjah," Int. J. Electr. Comput. Eng., vol. 11, no. 5, pp. 3671-3681, 2021, doi: 10.11591/ijece.v11i5.pp3671-3681.

[7] M. R. Maghami, H. Hizam, C. Gomes, M. A. Radzi, M. I. Rezadad, and S. Hajighorbani, "Power loss due to soiling on solar panel: A review," Renew. Sustain. Energy Rev., vol. 59, pp. 1307-1316, 2016, doi: 10.1016/j.rser.2016.01.044.

[8] P. Vasiljev, S. Borodinas, R. Bareikis, and A. Struckas, "Ultrasonic system for solar panel cleaning," Sensors Actuators, A Phys., vol. 200, pp. 74-78, 2013, doi: 10.1016/j.sna.2013.01.009.

[9] S. Nižetić, D. Čoko, A. Yadav and F. Grubišić-Čabo, "Water spray cooling technique applied on a photovoltaic panel: The performance response," Energy Convers. Manag., vol. 108, pp. 287-296, 2016, doi: 10.1016/j.enconman.2015.10.079.

[10] H. M. Bahaidarah, S. Rehman, P. Gandhidasan, and B. Tanweer, "Experimental evaluation of the performance of a photovoltaic panel with water cooling," Conf. Rec. IEEE Photovolt. Spec. Conf., 2013, pp. 2987-2991, doi: 10.1109/PVSC.2013.6745090.

[11] K. W. Abid, B. H. Sulaiman, O. I. Abd, and H. A. Rahman, "Study the impact of the ideality factor and the dust on the performance of solar panels," J. Green Eng., vol. 10, no. 6, pp. 2615-2626, 2020. 
[12] H. Kawamoto and T. Shibata, "Electrostatic cleaning system for removal of sand from solar panels," J. Electrostat., vol. 73, pp. 65-70, 2015, doi: 10.1016/j.elstat.2014.10.011.

[13] M. A. Alghamdi et al., "Characterization and elemental composition of atmospheric aerosol loads during springtime dust storm in western Saudi Arabia," Aerosol Air Qual. Res., vol. 15, no. 2, pp. 440-453, 2015, doi: 10.4209/aaqr.2014.06.0110.

[14] M. Abderrezek, M. Fathi, S. Mekhilef, and F. Djahli, "Effect of temperature on the GaInP/GaAs tandem solar cell performances," Int. J. Renew. Energy Res., vol. 5, no. 2, pp. 629-634, 2015, doi: 10.20508/ijrer.80280.

[15] E. Molenbroek, D. W. Waddington, and K. A. Emery, "Hot spot susceptibility and testing of PV modules," Conf. Rec. IEEE Photovolt. Spec. Conf., vol. 1, 1992, pp. 547-552, doi: 10.1109/pvsc.1991.169273.

[16] V. P. Sethi, K. Sumathy, S. Yuvarajan, and D. S. Pal, "Mathematical Model for Computing Maximum Power Output of a PV Solar Module and Experimental Validation," J. Fundam. Renew. Energy Appl., vol. 2, pp. 1-5, 2012, doi: 10.4303/jfrea/r120312.

[17] M. S. Bin Ishak, R. H. Salimin, I. Musirin, and Z. A. Hamid, "Development of PV array configuration under different partial shading condition," Int. J. Power Electron. Drive Syst., vol. 10, no. 3, pp. 1263-1269, 2019, doi: 10.11591/ijpeds.v10.i3.1263-1269.

[18] S. Dubey, J. N. Sarvaiya, and B. Seshadri, "Temperature dependent photovoltaic (PV) efficiency and its effect on PV production in the world - A review," Energy Procedia, vol. 33, pp. 311-321, 2013, doi: 10.1016/j.egypro.2013.05.072.

[19] M. Al-Jumaili and B. Karimi, "Maximum bottleneck energy routing (MBER)-An energy efficient routing method for wireless sensor networks," 2016 IEEE Conf. Wirel. Sensors, ICWiSE 2016, vol. 2017-Decem, no. December, pp. 38-44, 2016, doi: 10.1109/ICWISE.2016.8187759.

[20] B. V. Chikate and Y. Sadawarte, and Assistant Professor BDCOE Sewagram, "The Factors Affecting the Performance of Solar Cell," Int. J. Comput. Appl. Sci. Technol., pp. 975-8887, 2015.

[21] J. K. Kaldellis, M. Kapsali and K. A. Kavadias, "Temperature and wind speed impact on the efficiency of PV installations. Experience obtained from outdoor measurements in Greece," Renew. Energy, vol. 66, pp. 612-624, 2014, doi: 10.1016/j.renene.2013.12.041.

[22] M. H. Al-Jumaili, H. M. Haglan, M. K. Mohammed, and Q. H. Eesee, "An automatic multi-axis solar tracking system in Ramadi city: Design and implementation," Indones. J. Electr. Eng. Comput. Sci., vol. 19, no. 3, pp. 1226-1234, 2020, doi: 10.11591/ijeecs.v19.i3.pp1126-1234.

[23] B. Yerli, M. K. Kaymak, E. Izgi, A. Oztopal, and A. D. Sahin, "Effect of Derating Factors on Photovoltaics under Climatic Conditions of Istanbul," World Acad. Sci. Eng. Technol., vol. 4, no. 8, pp. 1303-1307, 2010.

[24] L. Dorobanț, M. O. Popescu, C. L. Popescu, and A. Crăciunescu, "Renewable Energy and Power Quality Journal (RE\&amp;PQJ) Experimental Assessment of PV Panels Front Water Cooling Strategy," Renew. Energy Power Qual. J., vol. 1, no. 11, pp. 1009-1012, 2013.

[25] G. N. Tiwari, S. Tiwari, V. K. Dwivedi, S. Sharma and V. Tiwari, "Effect of water flow on PV module: A case study," Int. Conf. Energy Econ. Environ.-1st IEEE Uttar Pradesh Sect. Conf. UPCON-ICEEE 2015, 2015, doi: 10.1109/EnergyEconomics.2015.7235080.

[26] Anon, 2017b. SUNTECH 250 Watt monocrystalline solar module datasheet. [Online]. Available: https://es-mediaprod.s3.amazonaws.com/media/u/bad/9e9/d9b/4a377fac554a5266604e7b20285d4e78/SuntechWdmono(MC4_250 _255_260_265)_EN_web.pdf

\section{BIOGRAPHIES OF AUTHORS}

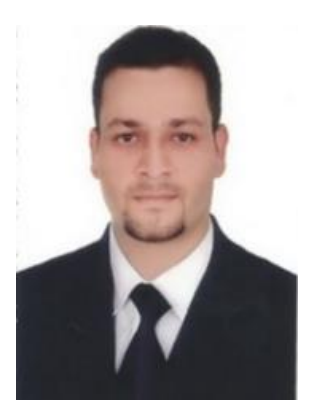

Ahmed Khudhair Abbas received his bachelor's degree in the Department of Electrical Power Techniques Engineering from the Al-Mamon University College in Baghdad, (2012). Where he also obtained his Master of Science (M.Sc.) degree in 2015 in school of Electrical system engineering (Electrical Power Engineering) from University Malaysia Perlis (UniMAP) in Malaysia. In 2016, he became an assistant lecturer in Anbar University. He is presently working in a University Headquarter, Construction and Projects Department in Anbar University, Iraq. His areas of interest are Power Quality, Control Systems engineering, Power Electronics, MATLAB Simulation, Renewable Energy Technologies, and Power System Protection.

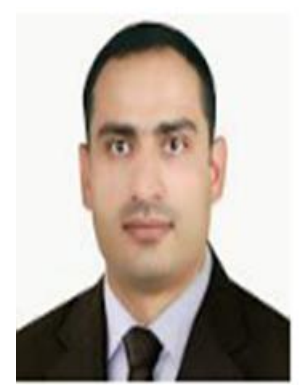

Kaleid waleed Abid received the B.S degree in electrical engineering from Al-Mustansiriyah University, Baghdad, Iraq in 2005 and the M.S. degree in electrical engineering from Gaziantep University, Gaziantep, turkey, in 2018. He is a member of renewable energy research center. His research interests include solar inverter modeling and practical, performance evaluation of solar panel, PV module test, analysis of distortion signal at electrical distribution. He published more than ten papers in international journals. 


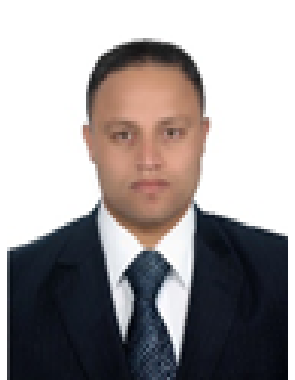

Osama Ibrahim Abd He received the B.Sc. degree in Production and Metallurgical Engineering Department from the University of Technology-Iraq in 2003, M.Sc. degree in Metallurgical Engineering from the university of technology-Iraq in 2012. Since 2012, he has been working with the University of Anbar-Iraq, where he is a lecturer at mechanical engineering department and he is a researcher at Renewable Energy Research Center (RERC). Osama participated in UMPEDAC Training Course in RENEWABLE ENERGY on $10^{\text {th }}-21$ th December 2012 at University of Malaya (UM)-Malaysia. In addition, he completed the course "RE100: Introduction to Renewable Energy" on December 2014 at Solar Energy International (SEI). His research interests include statistical analysis and modeling, Semi-Solid processing, metallic foam, microstructural characterization, PV efficiency, Solar Air Heaters (SAHs), and renewable energy resources. He published more than ten papers in local and international journals.

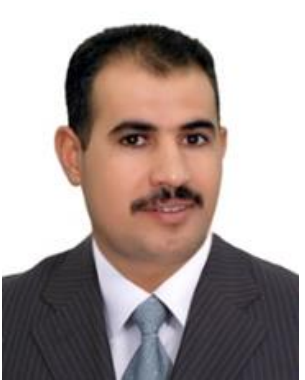

Assist. Prof. Dr. Yousif Ismail Mohammed Al Mashhadany is a lecturer in Electrical Engineering Department - College of Engineering (Control Engineering). Senior member IEEE, He received the B.Sc. (1995), M.Sc. (1999), and Ph.D (2010) in Department of Electrical and Electronic Engineering from the Rashid School of Engineering and Science/University of Technology in Baghdad/Iraq. He completes postdoctoral fellow research in Electrical Engineering-Control Department at the University of Malaya in Malaysia (UMPEDAC) in 2012. He works since 2004, a lecturer in the Department of Electrical Engineering/Engineering College/University of Anbar. He has many publishing that included three books, two chapters, thirty seven Journals paper most of them (Clarivate, Scopus and international journal), and thirty two conferences paper.

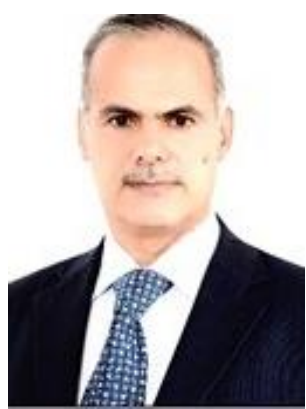

Abdul-Rahman Hammad jasim received the B.S degree in science of physics from AlMustansiriyah University, Baghdad, Iraq in 1958 and the M.S. degree in electrical engineering from University of Al Anbar, Aanbar, Iraq, in 2017. He is a member of renewable energy research center. His research interests include solar inverter modeling and practical, SemiSolid processing, metallic foam, microstructural characterization, PV efficiency test, image processing. He published more than seven papers in international journals. 